\title{
A new species of gall midge associated with Diplopterys pubipetala (A.Juss.) Anderson and Davis (Malpighiaceae) from Altinópolis, São Paulo, Brazil
}

\author{
Urso-Guimarães, MV. ${ }^{*}$ and Carmo-Neto, AM. ${ }^{a}$
}

\begin{abstract}
${ }^{a}$ Laboratório de Diversidade Animal, Departamento de Biologia, Universidade Federal de São Carlos - UFSCar, Campus Sorocaba, Rodovia João Leme dos Santos, SP-264, Km 110, Bairro do Itinga, CEP 18052-780, Sorocaba, SP, Brazil

*e-mail: virginia@ufscar.br
\end{abstract}

Received: June 18, 2013 - Accepted: August 20, 2013 Distributed: March 31, 2015

(With 14 figures)

\begin{abstract}
Clinodiplosis bellum sp. nov. associated with Diplopterys pubipetala (A.Juss.) Anderson and Davis (Malpighiaceae) from Brazil are described. This is the first species of Clinodiplosis described to State of São Paulo and the first formal description of Diplopterys pubipetala (Malpighiaceae) as host plant of Cecidomyiidae species. Description and illustration of the Clinodiplosis bellum sp. nov. (Diptera: Cecidomyiidae) are given.
\end{abstract}

Keywords: Clinodiplosis, gall maker, Neotropical region, taxonomy.

\section{Nova espécie de galhador associado a Diplopterys pubipetala (A.Juss.) Anderson and Davis (Malpighiaceae) de Altinópolis, São Paulo, Brasil}

\section{Resumo}

Clinodiplosis bellum sp. nov. associada a Diplopterys pubipetala (A.Juss.) Anderson and Davis (Malpighiaceae) do Brasil é descrita. Esta é a primeira espécie de Clinodiplosis descrita para o Estado de São Paulo e a primeira descrição formal de Diplopterys pubipetala (Malpighiaceae) como planta hospedeira de uma espécie de Cecidomyiidae. Descrição e ilustrações de Clinodiplosis bellum sp. nov. (Diptera: Cecidomyiidae) são apresentadas.

Palavras-chave: Clinodiplosis, galhador, Região Neotropical, taxonomia.

\section{Introduction}

The family Cecidomyiidae has more than 6,000 species in five subfamilies Catotrichinae, Lestremiinae, Mycromyiinae, Porricondylinae, and Cecidomyiinae. Cecidomyiinae is the largest subfamily of gall midges, with 595 genera and 4,763 known species. It is organized in four supertribes, one of which is the Cecidomyiidi, organized in 11 tribes. One of these tribes is Clinodiplosini, a cosmopolitan tribe of 193 species organized in 28 genera (Gagné, 2010). In this paper, a new species of Clinodiplosis is described.

Clinodiplosis Kieffer, 1895 is a cosmopolitan genus with 120 species, of which about 23 occur in the Neotropical Region, 17 in Brazil. The mainly habits of Neotropical species is the phytophagy, with some species that cause complex galls in several families of plants as Asteraceae, Labiaceae, Melastomataceae, Moraceae, Orchidaceae, Rubiaceae, Solanaceae, and Verbenaceae (Gagné 1994, 2010).

The new species of Clinodiplosis was obtained from conic leaf galls in Diplopterys pubipetala (A.Juss.) Anderson and Davis (Malpighiaceae). D. pubipetala, also known as "cipó-de-pomba" or "tingüi", is a plant species native from Brazil, component of many Brazilian phitogeographic dominions, including Brazilian cerrado (Brazilian savanna). This plant is a liana referred as pioneer with large regeneration capacity on disturbed areas (Pott and Pott, 1986).

This is the first report of Clinodiplosis to State of São Paulo and the first formal description of Diplopterys pubipetala (Malpighiaceae) as host plant of Cecidomyiidae species.

\section{Methods}

Samples of galls of Diplopterys pubipetala (Malpighiaceae) were collected from March, 2000 to May, 2001 in a natural area of seasonally tropical dry wood, in Altinópolis $\left(21^{\circ} 1^{\text {' }}\right.$ 26 " S, $47^{\circ} 22$ ' 22" W), State of São Paulo, Brazil. Conic leaf galls of D. pubipetala were sampled and transferred to individual plastic bags, for rearing the adults. Some of the galls were dissected under stereomicroscope to obtain immature. All material was conserved in 70\% alcohol and later mounted in slides. Slide mounting technique followed 
Gagné (1994). The cecidomiid species was identified based on the key of Cecidomyiidae, in Gagné (2009). All types will be deposited at the Museu de Zoologia of the Universidade de São Paulo, São Paulo, Brazil (MZUSP). The plant species was identified by Dra. Olga KotchekoffHenriques (Secretaria de Meio Ambiente da Prefeitura Municipal de Ribeirão Preto).

\section{Results}

Clinodiplosis Kieffer, 1895.

Diagnosis: $\mathrm{R} 5$ longer than it and joining $\mathrm{C}$ beyond its apex; tarsal claws variable, untoothed or toothed on forelegs, curved on basal third or beyond the midlength, empodia shorter than claws; male cerci may be rectangular or triangular, lobed or non lobed; female ovipositor short or barely protrusible and female cerci separate with two larger setae on apex.

Clinodiplosis bellum Urso-Guimarães and Carmo-Neto sp. nov. (Figures 1-14).

Description. Adult. Body orange. Body length, $4 \mathrm{~mm}$ (male, $\mathrm{n}=4$ ); 5 mm (female, $\mathrm{n}=5$ ). Eyes black, holoptic, facets hexagonal, closely adjacent. Occipital process present. Labellum completely setose; palpus total length, $0.27 \mathrm{~mm}$ (male and female), palpus 4-segmented, each palpomere setose as Figure 1; first and fourth palpomeres length 0.06 $\mathrm{mm}$, second and third $0.08 \mathrm{~mm}$ (male and female). Antennae total length, $3 \mathrm{~mm}$ (male) and $2.5 \mathrm{~mm}$ (female); scape and pedicel length and maximum width, $0.12 \mathrm{~mm}$; scape broader distally; 12 binodal tricircumfilar flagellomeres in males and cylindrical flagellomeres in females; male: first to twelfth flagellomeres $0.25 \mathrm{~mm}$ length; female: first to twelfth flagellomeres $0.2 \mathrm{~mm}$ length; circumfila and ornamental setae of male and female flagellomere 3 as in Figures 2 and 3, respectively, last flagellomere with stalk (Figure 4). Thorax. Dorsal region of antepronotal lobe with a group of setae. Scutum and scutelum dark brown. One row of dorsocentral setae, lateral prealar (or humeral) and postalar setae joined in a unique row in the scutum; scutelum completely covered by setae; anepistern with eighteen setae; katepistern bare; anepimeron with three rows of setae in its middle portion; mediotergite bare; laterotergite with three trichoid sensila near halter base. Legs: forelegs total length, $3.6 \mathrm{~mm}$ (male and female); middlegs and hindlegs total length, $4 \mathrm{~mm}$ (male and female); first tarsomere without spur; tarsal claws simple in all legs, length, $0.15 \mathrm{~mm}$ (male and female), bent midlength to apex; empodia shorter than claws (Figure 5), length, $0.03 \mathrm{~mm}$ (male and female). Wing length, $3 \mathrm{~mm}$ (male), $3.2 \mathrm{~mm}$ (female); width, $1.2 \mathrm{~mm}$; hyaline, venation as in Figure $6 ; \mathrm{R}_{5}$ joining $\mathrm{C}$ beyond apex. Halter: length, 0.5 $\mathrm{mm}$ (male and female); light brown; completely covered of micro setae.

Abdomen: Tergites 1-7 rectangular with complete sclerotization, and a complete row of posterior setae, in males and females; T8 not sclerotized in males and females. Sternites 1-8 with complete sclerotization in males and S1-7 in females. Trichoid sensilla absent in tergites and sternites in males and females. Male terminalia (Figures 7,8 ) total length, $0.6 \mathrm{~mm}$ : gonocoxites splayed large with mesobasal lobe triangular with rounded apex; setae placed only on external surface; gonostylus narrow, sparsely covered with setae and microsetulae, placed at apex of gonocoxite, gonostylus teeth entire; aedeagus with a constriction in apex, longer than hypoproct, hypoproct bilobed with few strong setae at apex; cerci rectangular, deeply bilobed, covered by strong setae. Female terminalia (Figure 9): ovipositor barely protrusible, length, $0.5 \mathrm{~mm}$; cerci ovoid, separate and setose (two apical setae stronger than the others); hypoproct sligthly bilobed and covered by setulae.

Pupa (Figures 10, 11). Body light brown. Body length, $4.5 \mathrm{~mm}$; maximum width, $1.2 \mathrm{~mm}(\mathrm{n}=5)$. Head (Figure 10). Antennal horns, $0.6 \mathrm{~mm}$, serrate all around the edge, cephalic setae, $0.3 \mathrm{~mm}$ length. Thorax: upper and lower frontal horn absent, a pair of lower facial papillae (one setose and one bare) each side of midline, three lateral papillae (one setose and two bare) each side of midline, prothoracic spiracle cylindrical, $0.9 \mathrm{~mm}$ (Figure 10); wing reaching fourth abdominal segment; first and third pairs of legs reaching seventh abdominal segment, second pair reaching eighth. Abdomen. Tergites covered by sparse tiny spines (Figure 11). Terminal segment length, $0.02 \mathrm{~mm}$; width, $0.04 \mathrm{~mm}$. Pupation in gall.

Larva (Figures 12, 13). Third instar. Body length, 3,5 $\mathrm{mm}$; maximum width, $1 \mathrm{~mm}(\mathrm{n}=4)$. Collar segment with two very large papillae without setae in dorsal region; dorsal sclerotized plate occupying pro and mesothorax with a row of setae on superior margin; pleural papillae very well developed and one spiracle each side of the plate (Figure 12). Prothoracic spatula and lateral papillae absent. Terminal segment length, $0.3 \mathrm{~mm}$; maximum width $0.5 \mathrm{~mm}$; round; anus opening in ventral region; terminal segment with four pairs of setose papillae not corniform (one setae long, one median and two short) not placed in lobes (Figure 13).

Holotype: Male, emerged from leaf galls in Diplopterys pubipetala, Brazil, State of São Paulo, Altinópolis. Collection, 15.iii.2000, emergence, 16.iii.2000. Urso-Guimarães, MV.; Balbi, MIPA.

Paratypes: Same as holotype except for: emergence, 16.iii.2000, 11 females, 12 pupal exuviae, 6 pupae; emergence, 17.iii.2000, one male, 11 females, 12 pupal exuviae; emergence, 19.iii.2000, one male, 16 females, 17 pupal exuviae, two larvae; emergence, 21.iii.2000, one male, three pupal exuviae; emergence, 22.iii.2000, one female. Collection, 28.v.2001, two larvae, Urso-Guimarães, MV.; Balbi, MIPA. and Mendes, HF.

Distribution. Brazil: State of São Paulo, Santa Rita do Passa Quatro, Cerrado Pé-de-Gigante (Urso-Guimarães and Scareli-Santos, 2006) and State of São Paulo, Altinópolis (this paper).

Etymology: The specific epithet of is the species is in honor of Maria Isabel Protti de Andrade Balbi (Bel), one of the collectors and very helpful in field and laboratory activities. 

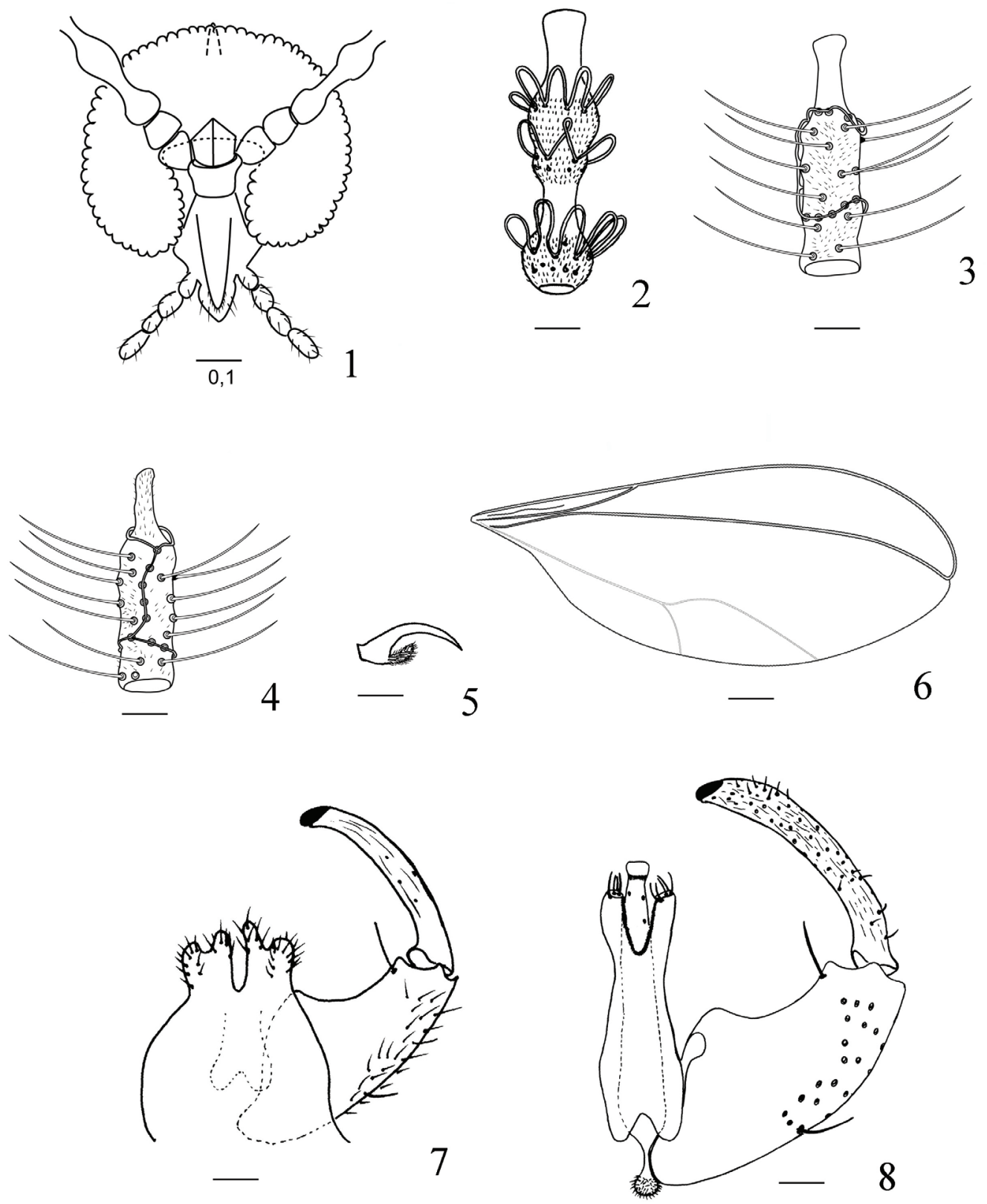

Figures 1-8. Clinodiplosis bellum sp. nov. 1. female head, frontal view; 2. male flagellomere 3; 3. female flagellomere 3; 4. female apical flagellomere; 5 . tarsal claw; 6. wing; 7. male terminalia, dorsal view; 8 . male terminalia, dorsal view without cerci. Scale bars in $\mathrm{mm}$.

Galls (Figure 14): In conic leaf galls of Diplopterys pubipetala (Malpighiaceae), color green to brown, both sides of leaf, unilocular, glabrous.

Remarks. The main features to distinguish Clinodiplosis bellum sp. nov. of the described species are: larval prothoracic spatula absent, collar segment with two very large papillae without setae in dorsal region; dorsal sclerotized plate occupying pro and mesothorax, lacking central papillae in mesothorax; pleural papillae very well developed in prothorax; terminal segment with four pairs of setose papillae (one setae long, one median and two short) not placed in lobes. Pupal antennal horns serrate all around the edge.

\section{Discussion}

All species of neotropical Clinodiplosis with described larva has prothoracic spatula and two groups of three lateral papillae each side. In C.bellum sp. nov. prothoracic spatula and lateral papillae are absent. The remarkable feature in 

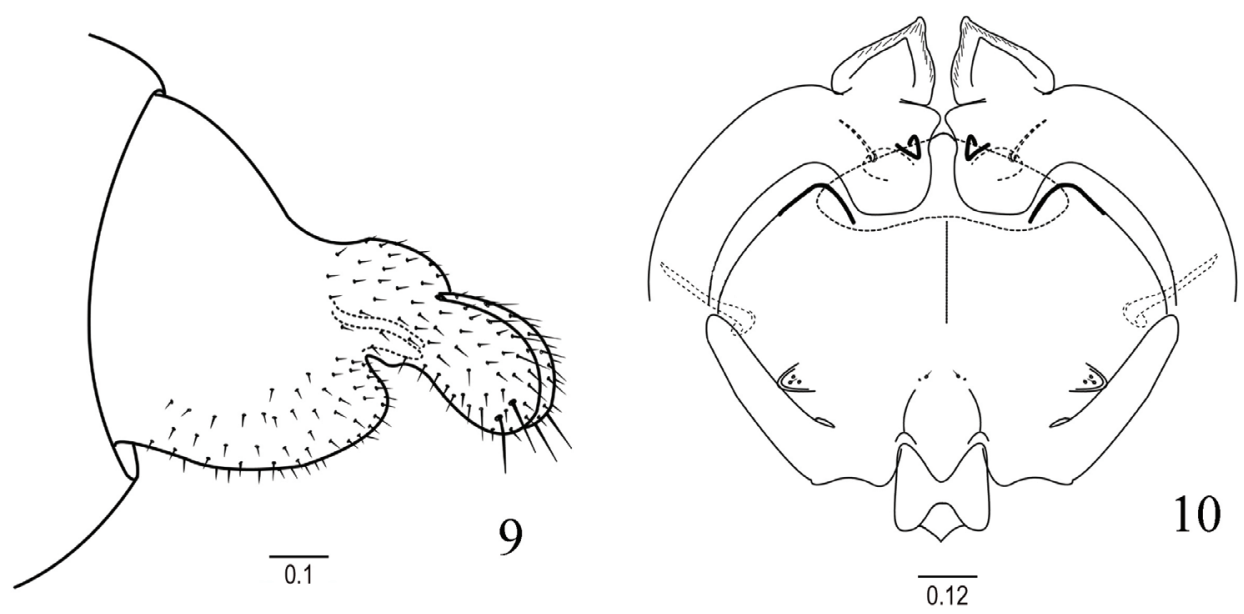

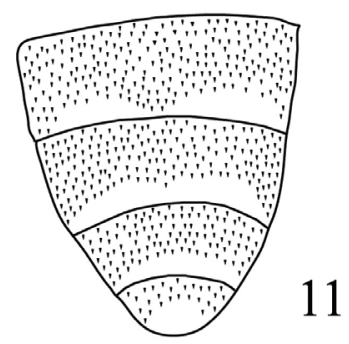

$\overline{0.26}$

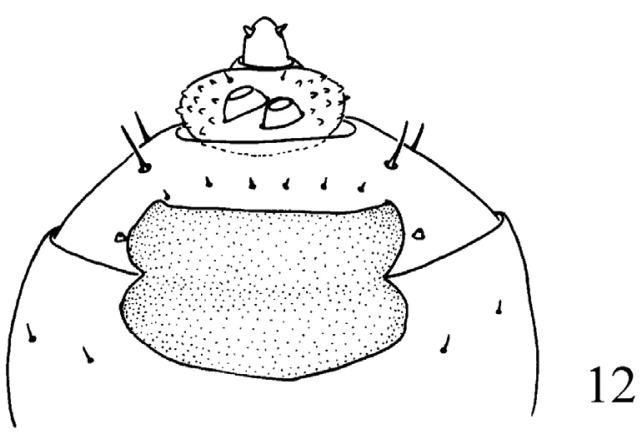

$\overline{0.13}$
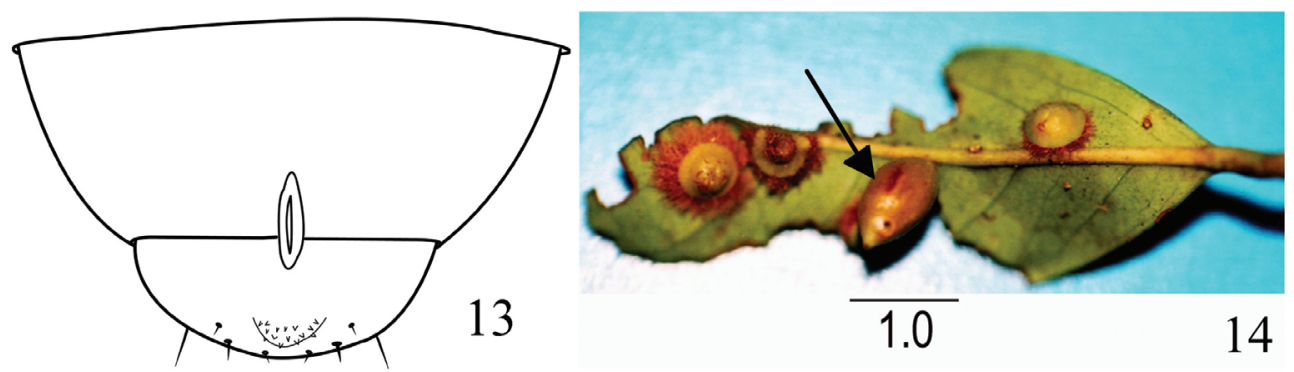

$\overline{0.12}$

Figures 9-14. 9. Clinodiplosis bellum sp. nov. female terminalia, lateral view; 10. pupal head, ventral view; 11. pupal posterior segments, ventral view; 12. larval anterior region, dorsal view; 13. larval terminal segment, ventral view; 14. leaf gall of Diplopterys pubipetala (A.Juss.) Anderson and Davis (Malpighiaceae) (arrow on gall). Scale bars in $\mathrm{mm}$.

this new species are the presence of two very large papillae without setae in dorsal region of collar segment, and dorsal sclerotized plate occupying pro and mesothorax, absent in other neotropical species of Clinodiplosis. The larva of the new species differs from other neotropical species of
Clinodiplosis in the setae of terminal segment, four pairs of setose papillae, not corniform, and not placed in lobes in C.bellum sp. nov. shared with C. profusa Maia, 2001. The pupa features of C.bellum sp. nov., antennal horns of median length and serrate all around the edge, and presence 
of small spines in the dorsal abdominal region, differ from the other neotropical species of Clinodiplosis, that has very discrete antennal horns and well developed dorsal spines. The male flagellomeres of C.bellum sp. nov. are tricircumfilar, with loops of equal size, as $C$. conica Oliveira and Maia, 2008; C. dioidae Maia, 2001; C. melissae Maia, 1993; and C. cearensis Tavares, 1917. The number of palpomeres in C.bellum sp. nov. is 4, different only from C. pulchra Tavares, 1917 and C. rubiae Tavares, 1918, with 5 palpomeres and from C. eupatorii Felt, 1911 with 3. The tarsal claws are simple in C.bellum sp. nov., as the majority of the Clinodiplosis species, but the claws are curved at the midlength, instead as C. alternantherae Gagné, 2004; C. conica, C. melissae, C. eupatorii, C. rubiae, C. bahiensis Tavares, 1917; C. iheringi Tavares, 1925; C. cattleyae Molliard, 1903 which claws are curved after midlength, and C. dioidae, C. floricola Novo Guedes and Maia, 2008; C. profusa Maia 2001; C. costai Maia, 2005; C. maricaensis Maia and Fernandes, 2011, and C. marcetiae Tavares, 1917, that has the claws bent before $1 / 3$. The male terminalia of C.bellum sp. nov. is very similar to the other Clinodiplosis species, with cerci rectangular deeply bilobed, hypoproct deeply bilobed, mesobasal lobe triangular, with rounded apex and aedeagus tapering to the apex. The remarkable feature is the constriction in the aedeagus apex, shared only with C. melissae and C. profusa. Additionally, this is the only Clinodiplosis species inducing galls in Diplopterys pubipetala (Malpighiaceae).

\section{Acknowledgements}

The authors acknowledge the support from FAPESP grant \#99/01429-1, Dalton de Souza Amorim, Ma Isabel Protti de Andrade Balbi (FFCLRP/USP), and Olga KotchekoffHenriques (SMMA/PMRP).

\section{References}

GAGNÉ, RJ., 1994. The gall midges of the neotropical region. Ithaca: Cornell University Press. p. 352.

GAGNÉ, RJ., 2009. Family Cecidomyiidae. In BROWN BV, BORKENT A, CUMMING JM, WOOD DM, WOODLEY NE and ZUMBADO M. Manual of Central American Diptera. Ottawa: NRC Research Press. p. 293-314. vol. 1.

GAGNÉ, RJ., 2010. Update for a catalog of the Cecidomyiidae (Diptera) of the world. Digital version 1. Available from: $<\mathrm{http}: / /$ www.ars.usda.gov/SP2UserFiles/Place/12754100/Gagne_2010_ World_Catalog_Cecidomyiidae.pdf $>$

POTT, VJ. and POTT, A., 1986. Plantas colonizadoras da estrada transpantaneira (da Fazenda Leque ao Retiro Chatelodo), na Nhecolândia, Pantanal. Corumbá: Embrapa Pantanal. 9 p. Embrapa Pantanal. Comunicado Técnico, 7.

URSO-GUIMARÃES, MV. and SCARELI-SANTOS, C., 2006. Galls and gall makers in plants from the Pé-de-Gigante Cerrado Reserve, Santa Rita do Passa Quatro, SP, Brazil. Revista Brasileira de Biologia = Brazilian Journal of Biology, vol. 66, no. 1B, p. 357-369. http://dx.doi.org/10.1590/S1519-69842006000200018. PMid:16710528 